\title{
PENGGUNAAN APD SEBAGAI ANTISIPASI KECELAKAAN KERJA DI BERBAGAI UNIT RUMAH SAKIT DAN PENGARUH STRES PADA KECELAKAAN KERJA PERAWAT
}

\author{
Audina Tio Junianti Manik \\ Email : audina.junianti@gmail.com
}

\section{Latar Belakang}

Perawat memiliki beban kerja yang dapat dikatakan pekerjaan dengan resiko tinggi, karena perawat adalah profesi yang memiliki peran penting dalam meningkatkan kesehatan pasien, serta yang membutuhkan kecepatan dan ketepatan pada saat menangani pasien, terutama pasien yang dalam keadaan gawat darurat. Beban kerja yang dialami perawat pun tidak menutup kemungkinan perawat mengalami stress serta kelelahan yang menyebabkan kecelakaan kerja pada saat menjalankan tugasnya. Kecelakaan adalah kejadian tidak terduga yang disebabkan oleh tindakan tidak aman dan kondisi tidak aman (Heinrich, 1930).

Pada penelitian The National Institute Occupational Safety and Health (NIOSH) menunjukkan bahwa pekerjaan-pekerjaan yang berhubungan dengan rumah sakit atau kesehatan memiliki kecenderungan tinggi untuk terkena stres kerja atau depresi, sedangkan American National for Occupational Health (ANAOH) menempatkan kejadian stres kerja pada perawat berada diurutan paling atas dari empat puluh pertama kasus stres kerja pada pekerja (Rahman,
2010) $)^{[12]}$.

Stress bisa saja terjadi karena perawat mengalami kelelahan. Terdapat dua jenis kelelahan yaitu kelelahan otot dan kelelahan umum. Kelelahan otot merupakan tremor pada otot. Kelelahan umum ditandai dengan berkurangnya kemauan untuk bekerja yang sebabnya adalah persyaratan psikis. Penyebab kelelahan umum adalah monotoni, intensitas, dan lamanya kerja mental dan fisik, keadaan lingkungan (Suma'mur, 2009) ${ }^{[5]}$. Dan tidak heran, jika seorang perawat yang mengalami kelelahan akibat stress tersebut rentan terhadap kecelakaan kerja, seperti salah satunya adalah ketidakfokusan perawat dalam melakukan asuhan keperawatan.

Selain dari kelelahan dan stres, kurangnya pengetahuan perawat akan tindakan aman selama melakukan asuhan keperawatan juga dapat menjadi salah satu penyebab terjadinya kecelakaan kerja pada perawat.

Dari pernyataan diatas maka penulisan ini dilakukan untuk membahas mengenai pencegahan atau antisipasi kecelakaan kerja di berbagai unit rumah sakit. 


\section{Metode}

a) Didalam penulisan ini, saya menggunakan metode menganalisis dengan cara mengumpulkan beberapa jurnal dari internet, membacanya, dan juga mengkompilasi isi dari berbagai jurnal tersebut. Dan mengambil serta menetapkan beberapa jurnal sebagai pedoman penulisan ini.

b) Pada Jurnal pertama yang berjudul "HUBUNGAN PENGETAHUAN DAN SIKAP PERAWAT DENGAN TINDAKAN PENCEGAHAN INFEKSI DI RUANG ICU RUMAH SAKIT” oleh Suharto dan Ratna Suminar, metode yang digunakan adalah analitik dengan desain cross sectional dengan tujuan untuk melihat hubungan pengetahuan dan sikap perawat ICU tentang APD dengan tindakan pencegahan infeksi pada perawat di Rumah Sakit Tk II Putri Hijau. Penelitian ini di lakukan mulai bulan Januari sampai Maret 2016. Sampel dalam penelitian ini adalah perawat yang bertugas di Ruang ICU Rumah Sakit Tk II Putri Hijau sebanyak 23 orang dengan menggunakan teknik total sampling Analisis data ${ }^{[11]}$.

Pada jurnal kedua, yang berjudul "PENGGUNAAN APD DIPOLIKLINIK GIGI BERDASARKAN TINGKAT
PENGETAHUAN PERAWAT GIGI TENTANG PENYAKIT MENULAR” oleh Nova Herawati, Fitri Agusni dan Ika Ifitri menggunakan metode desain penelitian dengan pendekatan cross sectional. Penelitian ini di lakukan di seluruh Puskesmas di wilayah kerja Dinas Kesehatan Kota Bukittinggi dan Kota Payakumbuh dilakukan pada bulan Februari sampai bulan Maret tahun 2017. Populasi seluruh perawat gigi (30 Orang) perawat gigi bertugas di Poliklinik Gigi Puskesmas Kota Bukittinggi dan perawat gigi yang bertugas di Poliklinik Gigi Puskesmas Kota Payakumbuh. Teknik sampling yang digunakan adalah total sampling (30 orang) $)^{[2]}$.

Pada jurnal ketiga, yang berjudul "FAKTOR YANG BERHUBUNGAN DENGAN KEJADIAN KECELAKAAN KERJA PADA PERAWAT DI RUANG IGD RSU ANUTAPURA KOTA PALU" oleh Lusia Salmawati, Muh. Rasul dan Muh. Ryman Napirah menggunakan metode yang sama juga dengan jurnal pertama dan kedua, yaitu penelitian analitik dengan menggunakan pendekatan cross sectional dimana penelitian ini bertujuan untuk mempelajari dinamika kolerasi antara faktor-faktor yang berhubungan dengan Kecelakaan Kerja. Pengambilan sampel ini dilakukan 
dengan menggunakan cara total sampling, yaitu teknik pengambilan sampel dimana jumlah sampel sama dengan jumlah populasi. Besar sampel dalam penelitian ini sebanyak 31 orang $^{[7]}$.

\section{Hasil}

Pada jurnal pertama didapatkan hasil Hasil penelitian berdasarkan kajian di Rumah Sakit Tk II Putri Hijau, dengan statistik uji univariat dan bivariat Hasil uji statistik univariat didapatkan bahwa berdasarkan pengkategorian sub variabel pengetahuan tentang APD yang paling besar berada pada kategori kurang yaitu sebanyak 13 orang $(56,5 \%)$ dan selebihnya berada pada kategori baik sebanyak 10 orang $(43,5 \%)$ dan Sub variabel sikap menunjukan yang paling besar berada pada kategori baik yaitu sebanyak 15 orang $(65,2 \%)$ dan selebihnya berada pada kategori kurang sebanyak 8 orang (34,8\%). Dan variabel tindakan pencegahan menujukan bahwa yang paling besar berada pada kategori baik yaitu sebanyak 13 orang $(56,5 \%)$ dan selebihnya berada pada kategori kurang sebanyak 10 orang $(43,5 \%)$. Berdasarka hasil uji bivariat dengan statistik uji Chi-Square menunjukan: Terdapat hubungan pengetahuan tentang APD dengan tindakan pencegahan infeksi di Ruang ICU Rumah Sakit Tk II Putri Hijau ( $\mathrm{p}=0,024<0,05)$. Terdapat hubungan sikap dengan tindakan pencegahan infeksi di Ruang ICU Rumah Sakit Tk II Putri Hijau $(\mathrm{p}=0,026<0,05)^{[11]}$.
Pada junal kedua , 30 orang perawat gigi tersebut $100 \%$ berjenis kelamin laki-laki, dengan latar belakang pendidikan 83\% Diploma III dan 17\% masih SPRG. Tabel 1 menunjukkan bahwa perawat gigi dengan latar belakang pendidikan pada tingkat SPRG masih masih memiliki pengetahuan yang kurang tentang penyakit menular. Hasil menunjukan secara biologis terlihat ada hubungan penggunaan APD oleh perawat gigi dengan pengetahuan perawat gigi tentang penyakit menular. Hasil uji statistic membuktikan bahwa terdapat hubungan yang positif dan kuat antara pengetahuan perawat gigi tentang penyakit menular dengan penggunaan alat perlindungan diri (APD) yaitu nilai $r=0,886$ de ngan $p(0,00)<p(0.05)$. Nilai $R 2=0,786$ memberikan gambaran sumbangan tingkat pengetahuan tentang penyakit menular terhadap penggunaan APD oleh perawat gigi sebesar 78,6\% sedangkan 21,4\% lainnya disumbang oleh faktor lain. Persamaan garis regresi $\mathrm{Y}=-1,935+$ $0,264 * X^{[2]}$.

Pada jurnal ketiga, hasil analisis uji Chi Square nilai $p$ value $0,002(p \leq 0,05)$ menunjukkan adanya hubungan umur dengan kejadian Kecelakaan Kerja, jenis kelamin dengan kejadian Kecelakaan Kerja dengan nilai p value 0,019 $(\mathrm{p} \leq 0,05)$, penggunaan APD dengan kejadian Kecelakaan Kerja nilai $p$ value 0,007 ( $p \leq 0,05)$, peraturan K3 dengan kejadian Kecelakaan Kerja nilai $p$ value $0,006(p \leq 0,05)$, pelatihan $K 3$ 
dengan kejadian Kecelakaan Kerja nilai p value $0,007(p \leq 0,05)$, pengawasan dengan kejadian Kecelakaan Kerja nilai $p$ value 0,006 $(p \leq 0,05)$. Tidak ada hubungan masa kerja dengan kejadian Kecelakaan Kerja dengan nilai p value 0,083 (p > $0,05)^{[7]}$.

\section{Pembahasan}

Pada jurnal pertama, dari uji chi-square menunjukan bahwa ada hubungan antara pengetahuan perawat tentang Alat Pelindung Diri (APD) dengan tindakan pencegahan infeksi, hal ini dapat dilihat nilai $\mathrm{p}=0,024<\alpha=0,05$.

Karena semakin tinggi tingkat pengetahuan seseorang maka akan tahu tentang tindakan yang harus dilakukannya dalam hal ini tindakan untuk mencegah terjadinya infeksi baik terhadap perawat itu sendiri maupun terhadap pasien. Dari hasil analisa univariat didapat bahwa perawat yang telah melakukan tindakan pencegahan infeksi yaitu 56,5\%. Menurut Notoatmodjo (2007) Pengetahuan merupakan hasil dari tahu dan terjadi setelah orang melakukan penginderaan terhadap suatu objek tertentu. Pengindraan meliputi penglihatan, pendengaran, penciuman, rasa dan raba. Pengetahuan merupakan bagian dari perilaku yang tidak bisa diamati secara langsung oleh orang lain karena masih terjadi didalam diri manusia itu sendiri (covert behavior). Hasil penelitian ini sesuai dengan penelitian Ningsih (2013) yang menemukan bahwa terdapat hubungan antara tingkat pengetahuan dan motivasi perawat dengan perilaku pencegahan infeksi nosokomial di Rumah Sakit Umum Daerah Sukoharjo. Dari hasil analisa uji univariat sikap perawat ruang ICU Rumkit TK II Putri Hijau pada umumnya baik 15 orang $(65,2 \%)$. Hal ini menunjukan sikap dalam pencegahan infeksi nosokomial baik. Sikap positif ini akan berpengaruh terhadap perubahan sikap yang lebih baik melalui pengamatan dan penilaian modal peran sikap perawat yang baik, sehingga sikap yang baik diterapkan dan akan memberikan manfaat ke pasien pada penyembuhan. Menurut Alport (1954) yang dikutip oleh Notoatmodjo (2007) bahwa sikap mempunyai 3 komponen pokok yaitu: kepercayaan (keyakinan), ide dan konsep terhadap suatu objek, Kehidupan emosional atau evaluasi terhadap suatu objek dan Kecenderungan untuk bertindak (tend to behave ${ }^{[11]}$.

Pada jurnal kedua, berdasarkan penelitian yang telah dilakukan diketahui bahwa perawat gigi dengan pengetahuan kurang semuanya tidak menggunakan handscoond dan tidak melakukan cuci tangan sebelum melakukan tindakan. Belum adanya kesadaran perawat gigi akan bahaya yang mengancam dirinya menjadi penyebab hal ini. Kebersihan dan keselamatan tangan merupakan faktor yang penting dalam pengendalian infeksi silang di klinik gigi. Berbeda dengan perawat gigi yang memiliki pengetahuan dalam kategori 
baik semuanya menggunakan alat perlindungan diri yang dikategorikan kecuali kaca mata pelindung dan baju pelindung karena tidak tersedia. Lebih lengkapnya penggunaan APD oleh perawat gigi yang memiliki pengetahuan baik tentang penyakit menular kemungkinan disebabkan oleh tingginya pengetahuan mereka terhadap sumber bahaya (penyakit menular) sehingga mereka lebih memproteksi diri mereka salah satunya adalah dengan penggunaan APD. Hasil uji statistik juga menunjukkan adanya hubungan yang positif dan bermakna antara pengetahuan perawat gigi tentang penyakit menular terhadap penggunaan alat perlindungan diri di Poliklinik Gigi ditunjukkan dengan nilai $r$ sebesar 0,886 dengan $\mathrm{p}=0,05$ artinya semakin baik penge tahuan perawat gigi tentang penyakit menular maka akan semakin lengkap dan sesuai SOP perawat gigi dalam penggunaan APD. Pengetahuan perawat gigi tentang penyakit menular akan mempengaruhi penggunaan APD oleh perawat gigi karena jika perawat gigi mempunyai pengetahuan yang kurang terhadap potensi ataupun sumber bahaya dalam hal ini misalnya bahaya penyakit menular yang ada di lingkungan kerjanya, maka perawat gigi tersebut akan cenderung membuat suatu keputusan yang salah, misalnya perilaku penggunaan APD yang buruk. Sebaliknya jika perawat gigi memiliki penge tahuan yang tinggi terhadap potensi bahaya yang ada lingkungan kerjanya maka perawat gigi tersebut akan lebih memproteksi diri dari sumber bahaya tersebut salah satunya adalah dengan penggunaan APD yang lengkap karena penggunaan APD mampu meminimalkan penyebaran penyakit menular di klinik gigi. Hasil penelitian ini menunjukan bahwa pengetahuan merupakan salah satu faktor berpengaruh yang mendorong atau menghambat individu untuk berperilaku (dalam hal penggunaan APD). Hasil penelitian ini juga sejalan dengan penelitian pada tahun 2015 tentang Hubungan Perilaku Perawat dengan Kepatuhan Menggunakan Alat Perlindungan Diri sesuai SOP di Ruang Rawat Inap Badan Layanan Umum Daerah (BLUD) Rumah Sakit Konawe. Hasil uji analis menyatakan bahwa tingkat pengetahuan perawat memang memiliki hubungan yang "kuat" dengan kepatuhan menggunakan APD sesuai SOP di BLUD Rumah Sakit Konawe. cTindakan pencegahan dan pengendalian infeksi harus dilakukan secara menyeluruh baik oleh penyedia pelayanan kesehatan maupun oleh tenaga pelayanan kesehatan gigi. Kedua belah pihak ini harus sama-sama kuat untuk melakukan tindakan pencegahan dan pengendalian infeksi karena jika penyedia pelayanan telah menyediakan fasilitas, namun jika belum adanya kesadaran dan pengetahuan dari tenaga pelayanan kesehatan gigi maka infeksi tidak dapat dicegah serta dikendalikan secara maksimal dan begitupun sebaliknya. Ketetapan Menteri Kesehatan RI Pada tahun 2012 dalam Standar Pencegahan dan Pengendalian Infeksi Pelayanan Kesehatan Gigi 
dan Mulut di Fasilitas Pelayanan Kesehatan menyebutkan bahwa Dinas Kesehatan Kabupaten atau Kota bertanggung jawab untuk menjamin ketersediaan tenaga, fasilitas pelayanan, alat dan obat kesehatan gigi dan mulut skala Kabupaten atau Kota. Perawat gigi harus menggunakan APD, karena APD mampu mengisolasi perawat gigi dari bahaya di tempat praktik. Sedangkan menurut OSHA atau Occupational Safety and Healtd Administration, alat perlindungan diri mampu melindungi pekerja dari luka atau penyakit yang diakibatkan oleh adanya kontak dengan bahaya di tempat kerja, baik yang bersifat kimia, biologis, radiasi, fisik, elektrik, mekanik dan lainnya. ${ }^{[2]}$

Pada jurnal ketiga, membahas mengenai faktorfaktor umur, jenis kelamin, masa kerja, alat pelindung diri (APD), peraturan $\mathrm{K} 3$, pelatihan $\mathrm{K} 3$, pengawasan. Umur adalah lamanya hidup seseorang dalam tahun yang dihitung sejak dilahirkan. semakin tinggi umur seseorang maka semakin bertambah pula ilmu atau pengetahuan yang dimiliki karena pengetahuan seseorang diperoleh dari pengalaman sendiri maupun pengalaman yang diperoleh dari orang lain. Hasil penelitian yang dilakukan pada perawat di Ruang IGD Rumah Sakit Umum Anutapura Palu didapatkan hasil nilai $\mathrm{p}=0,002(\mathrm{p}<0,05)$, artinya terdapat hubungan umur dengan kejadian Kecelakaan Kerja. Hasil penelitian ini sejalan dengan penelitian yang menunjukkan terdapat hubungan umur, masa kerja, pelatihan K3, APD, sikap kerja, pelindung mesin, kondisi jalan dengan kejadian kecelakaan, hasil penelitian ini menunjukkan bahwa dari 120 responden sebanyak $24(20 \%)$ responden mengalami kecelakaan dan 96 (80\%) responden tidak pernah mengalami kecelakaan. Dari hasil uji statistik bivariat didapatkan ada hubungan antara umur dengan kecelakaan kerja dengan OR 4,709. Namun penelitian ini tidak sejalan dengan penelitian yang menunjukkan artinya tidak ada keterkaitan yang bermakna antara umur pekerja dengan kecelakaan kerja.

Selanjutnya adalah jenis kelamin. Jenis kelamin (seks) adalah perbedaan antara perempuan dengan laki-laki secara biologis sejak seseorang itu dilahirkan. perbedaan biologis dan fungsi biologis laki-laki dan perempuan tidak dapat ditukarkan diantara keduanya. Hasil penelitian yang dilakukan pada perawat di Ruang IGD Rumah Sakit Umum Anutapura Palu didapatkan hasil nilai $\mathrm{p}=0,019(\mathrm{p}<0,05)$, artinya terdapat hubungan jenis kelamin dengan kejadian Kecelakaan Kerja. Namun hasil penelitian ini berbanding terbalik dengan definisi oprasional dimana dalam definisi oprasional dinyatakan jenis kelamin yang memiliki resiko lebih tinggi mengalami kecelakaan kerja adalah perempuan, tapi hasil analisis uji Chi Square menunjukkan persentase kecelakaan lebih banyak terjadi pada laki-laki. Hasil penelitian ini sejalan dengan penelitian menunjukkan bahwa faktor yang 
berhubungan dengan kecelakaan kerja di Departemen Produksi PT. Bintang Makmur Sentosa Textil Industri adalah faktor jenis kelamin dan kelalaian dalam penggunaan APD serta kurang pengetahuan terhadap pekerjaan, dengan masing-masing nilai ( $p$ value 0,01 ), ( $p$ value 0,034$)$, dan (p value 0,001 ) (4). Namun hasil penelitian ini berbeda dengan penelitian yang menunjukkan bahwa ada lima variabel yang berhubungan dengan kecelakaan ringan yaitu vaiabel pengetahuan ( $\mathrm{p}$ value 0,002 ), kepatuhan terhadap prosedur ( $\mathrm{p}$ value 0,000 ), pengawasan ( $p$ value 0,02 ) dan housekeeping ( $p$ value 0,035 ). sedangkan variabel yang tidak berhubungan adalah variabel umur, jenis kelamin, lama kerja, reward and punishment, sosialisasi K3, dan unit kerja dengan ( $\mathrm{p}$ value $>0.05$ ).

Lalu ada masa kerja. Masa kerja adalah suatu kurun waktu atau lamanya tenaga kerja bekerja disuatu tempat. Pengalaman untuk waspada terhadap kecelakaan kerja bertambah baik sesuai denga pertambahan masa kerja dan lama bekerja di tempat kerja yang bersangkutan. Hasil penelitian yang dilakukan pada perawat di Ruang IGD Rumah Sakit Umum Anutapura Palu didapatkan hasil nilai $\mathrm{p}=0,083(\mathrm{p}<0,05)$, artinya tidak ada hubungan masa kerja dengan kejadian Kecelakaan Kerja. Hasil penelitian ini sejalan dengan penelitian yang dilakukan menunjukkan bahwa hasil penelitian terdapat hubungan antara variabel pendidikan dengan kecelakaan kerja dengan nilai $\mathrm{p}=0,015$. sedangkan variabel yang tidak berhubungan adalah umur, waktu kerja, unit kerja dan masa kerja dengan nila $\mathrm{p}=>0,05$ masingmasing $(0,067,0,119,0,580$ dan 0,055$)$. Namun Berbeda dengan hasil penelitian dengan menggunakan uji regresi linear berganda diperoleh faktor yang berhubungan dengan kecelakaan kerja adalah penggunaan APD, SOP, pelatihan, masa kerja dan pengawasan. Selanjutnya ada alat pelindung diri. Alat pelindung diri adalah alat yang digunakan untuk melindungi pekerja agar dapat memproteksi dirinya sendiri. pengendalian ini adalah alternatife terakhir yang dapat dilakukan bila kedua pengendalian sebelumnya belum dapat mengurangi bahaya dan dampak yang mungkin timbul. Alat pelindung diri (APD) adalah seperangkat alat keselamatan yang digunakan oleh pekerja untuk melindungi seluruh atau sebagian tubuh dari kemungkinan adanya paparan potensi bahaya lingkungan kerja terhadap kecelakaan dan penyakit akibat kerja. Hasil penelitian yang dilakukan pada perawat di Ruang IGD Rumah Sakit Umum Anutapura Palu didapatkan hasil nilai $\mathrm{p}=0,007(\mathrm{p}<0,05)$, artinya ada hubungan penggunaan Alat Pelindung Diri dengan kejadian Kecelakaan Kerja. Kebijakan/aturan Kesehatan dan Keselamatan Kerja (K3) adalah suatu pernyataan tertulis yang ditandatangani oleh pengusaha dan/atau pengurus yang memuat seluruh visi dan tujuan perusahaan, komitmen dan tekad melaksanakan kesehatan dan keselamatan kerja, serta kerangka 
dan program kerja yang mencakup kegiatan perusahaan secara menyeluruh yang bersifat umum atau operasional. Hasil penelitian yang dilakukan pada perawat di Ruang IGD Rumah Sakit Umum Anutapura Palu didapatkan hasil nilai $\mathrm{p}=0,006(\mathrm{p}<0,05)$, artinya ada hubungan peraturan K3 dengan kejadian dengan

Kecelakaan Kerja. Hasil penelitian ini sejalan dengan penelitian berdasarkan hasil analisis variabel peraturan (SOP) menggunakan uji Chi Square didapatkan nilai $\mathrm{p}=0,000$ yang berarti ada hubungan yang signifikan antara peraturan (SOP) dengan kecelakaan ringan.

Faktor lainnya adalah pelatihan K3. Hasil penelitian yang dilakukan pada perawat di Ruang IGD Rumah Sakit Umum Anutapura Palu didapatkan hasil nilai $\mathrm{p}=0,007$ ( $\mathrm{p}<0,05)$, artinya ada hubungan pelatihan $\mathrm{K} 3$ dengan kejadian dengan Kecelakaan Kerja. Hasil penelitian ini sejalan dengan penelitian berdasarkan hasil analisis untuk koefisien kolerasi spearman didapatkan koefisien kolerasi untuk faktor pelatihan dengan faktor kecelakaan kerja bernilai 0,292, berarti terdapat hubungan negatif antara faktor peltihan dan faktor kecelakaan kerja dengan demikian jika faktor pelatihan tinggi maka faktor kecelakaan rendah sedangkan jika faktor pelatihan rendah maka faktor kecelakaan tinggi, hasil uji kolerasi spearman antara faktor pelatihan dengan faktor kecelakaan kerja dapat diketahui terdapat hubungan yang signifikan dengan nilai signifikansi kurang dari 0.05. Dan faktor terakhir yang dibahas dalam jurnal ketiga ini adalah pengawasan. Pengawasan adalah suatu pekerjaan yang berarti mengarahkan yaitu memberi tugas, menyediakan intruksi, pelatihan dan nasihat kepada individu juga termasuk mendengarkan dan memecahkan masalah yang berhubungan dengan pekerjaan serta menanggapi keluhan bawahan. Hasil penelitian yang dilakukan pada perawat di Ruang IGD Rumah Sakit Umum Anutapura Palu didapatkan hasil nilai $\mathrm{p}=0,006(\mathrm{p}<0,05)$, artinya ada hubungan pengawasan dengan kejadian dengan Kecelakaan Kerja. Penelitian yang dilakukan denganmenggunakan desain Cross Sectional Study pada penelitian faktor-faktor yang berhubungan dengan kecelakaan kerja pada karyawan diperoleh hasil faktor yang berhubungan dengan kecelakaan kerja adalah pengawasan ( $\mathrm{p}$ value $>0.014) .{ }^{[7]}$

Dari pembahasan-pembahasan diatas, dapat disimpulkan bahwa pengantisipasian kecelakaan kerja di berbagai unit rumah sakit hampir sama, yaitu menggunakan APD (Alat Pelindung Diri). Dan APD pun salah satu dari bentuk prosedur (SOP) rumah sakit yang telah ditetapkan, baik dari pihak rumah sakit ataupun perarutan kementerian kesehatan. 


\section{Penutup}

Kecelakaan kerja yang terjadi pada perawat bisa saja terjadi karena stress akibat kelelahan dan beban kerja yang dialami perawat. Dan disini juga perawat membutuhkan motivasi atau kegiatan diluar jam dinas yang dapat menyegarkan atau merilekskan pikiran agar kegiatan perawat tidak monoton. Tetapi tidak lupa juga, bahwa pengetahuan perawat akan penggunaan alat pelindung diri juga dapat mencegah terjadinya kecelakaan kerja seperti penularan penyakit. Kepatuhan perawat akan penggunaan APD juga akan menentukan kesuksesan dalam kerjanya. Penggunaan APD juga telah ditetapkan dalam Standar Operasional Prosedur (APD) maupun Peraturan Menteri Kesehatan. Diharapkan kepada seluruh perawat atau calon perawat untuk lebih meningkatkan pengetahuan dan meningkatkan kesadaran diri akan pengantisipasian kecelakaan kerja, guna meminimalisir kecelakaan kerja pada perawat.

\section{Daftar Pustaka}

Bekarni, A. T., Anwar, T. R. P., Gerontini, R. (2019). HUBUNGAN MOTIVASI DENGAN KEPATUHAN PERAWAT DALAM PENGGUNAAN ALAT PELINDUNG DIRI (APD) DI RUANG RAWAT INAP RUMAH SAKIT TENTARA WIRASAKTI KUPANG. CHMK Health Journal, 3(2), 35-39.

Herawati, N., Agusni, F., Ifitri, I. (2017). PENGGUNAAN APD DIPOLIKLINIK GIGI BERDASARKAN TINGKAT PENGETAHUAN PERAWAT GIGI TENTANG PENYAKIT MENULAR. Jurnal Kesehatan Masyarakat Andalas, 12(1), 32-38.

Ibrahim, K., Mardiah, W., Priambodo, A. P. (2014). PENGETAHUAN, SIKAP, DAN PRAKTIK KEWASPADAAN UNIVERSAL PERAWAT TERHADAP PENULARAN HIV/AIDS. Jurnal Ners, 9(1), 11-18.

Maria, S., Wiyono, J., Candrawati, E. (2015).

KEJADIAN KECELAKAAN KERJA PERAWAT BERDASARKAN TINDAKAN

TIDAK AMAN. Jurnal Care, 3(2), 9-17.

Perwitasari, D., Tualeka, A. R. (2014). FAKTOR YANG BERHUBUNGAN DENGAN

KELELAHAN KERJA SUBYEKTIF PADA PERAWAT DI RSUD DR. MOHAMAD SOEWANDHIE SURABAYA. The Indonesian Journal of Occupational Safety, 1(1), 15-23. 
Salawati, L. (2012). PENGENDALIAN

INFEKSI NOSOKOMIAL DI RUANG

INTENSIVE CARE UNIT RUMAH SAKIT.

Jurnal Kedokteran Syiah Kuala, 12(1), 47-52.

Salmawati, L., Rasul, M., Napirah, M. R. (2019).

FAKTOR YANG BERHUBUNGAN DENGAN

KEJADIAN KECELAKAAN KERJA PADA

PERAWAT DI RUANG IGD RSU

ANUTAPURA KOTA PALU. Preventif : Jurnal

Kesehatan Masyarakat, 10(2), 104-112.

Simamora, R. H. (2017). A strengthening of role of health cadres in BTA-Positive Tuberculosis (TB) case invention through education with module development and video approaches in Medan Padang bulan Comunity Health Center, North Sumatera Indonesia. International Journal of Applied Engineering Research, 12(20), 1002610035.

Simamora, R. H., \& Saragih, E. (2019).

Penyuluhan kesehatan terhadap masyarakat:

Perawatan penderita asam urat dengan media audiovisual. JPPM (Jurnal Pendidikan dan Pemberdayaan Masyarakat), 6(1), 24-31.

Sitorus, E. D., Sunengsih, A. (2016). TINGKAT KEPATUHAN PERAWAT MENGENAI SOP DALAM PENGGUNAAN APD DI RUANG RAWAT BEDAH LT.12 BLOK.D RSUD KOJA JAKARTA UTARA TAHUN 2016. Jurnal Akademi Keperawatan Husada Karya Jaya, 2(2), 5-7.
Suharto, Suminar, R. (2016). HUBUNGAN PENGETAHUAN DAN SIKAP PERAWAT DENGAN TINDAKAN PENCEGAHAN INFEKSI DI RUANG ICU RUMAH SAKIT. Jurnal Riset Hesti Medan, 1(1), 1-9.

Suhaya, I., Sari, H. (2019). TINGKAT STRES

PERAWAT DALAM MERAWAT PASIEN DENGAN PENYAKIT MENULAR DI RUMAH SAKIT UMUM DAERAH dr. ZAINOEL ABIDIN BANDA ACEH. JIM FKEP, 4(1), 102-106. 
